\title{
Moderní migrace. Stěhování se zvláštním významem
}

\author{
Modern Migration. Movement with Special Significance
}

\author{
Kateřina Janků
}

ABSTRACT The text introduces modern migration as a phenomenon bound to the geopolitical organization of space according to the logic of the nation state. Generally speaking, social science treats modern migration either descriptively, adopting the notions of political regulation of migration, or they critically analyze these notions, looking for the conditions of their origin and bringing new terminology into the studies of migration. Diverse scientific discourses of migration are introduced through UN global migration statistics, discussion of the relevance of Geneva Convention in the contemporary world with the new term "bogus refugee" and general overview of disciplines that are dealing with migration. There are four relevant aspects of any theoretical approach to migration: whether it is conventional or critical towards the political discourse of migration, what level of analysis it prefers, what moment in a migration event it focuses on, and which disciplinary tradition it follows. Further, the major social science disciplines dealing with migration are introduced from these four aspects as well as their basic hypotheses. Finally, discussed also is that despite relatively small numbers of migrating people, modern migration events and concepts are bound up with the reconfiguration of the world geopolitical order and new understandings of social inequality and space.

KEY WORDS Geneva Convention, inequality, modern state regulations, scientific discourses on migration, space

\section{Úvod}

V současné době charakterizuje migraci především změna. Povaha migrování se s měnícími se možnostmi toku zboží, peněz a lidí proměňuje, stejně jako se mění vnímání migrace moderními společnostmi a s tím související politická regulace migrace (Barša a Baršová 2005). Sociální vědy přinášejí nástroje orientace v této spletité problematice a kritickou reflexi migračních událostí, opatření a používané terminologie. V neposlední řadě zvou k diskusi samotné nositele fenoménu migrace - migrující děti, muže a ženy.

Je patrné, že pojem migrace podstupuje v posledních letech proces zmnožování významů, v němž může dojít až k zahlcení významy a vyprázdnění pojmu. Tento text se pokouší čtenáře existující nepřebernou terminologickou směsicí provést. Představuje migraci jak jako fenomén, tak jako výzvu ke konceptuálnímu vyrovnání se s tímto „stěhováním se zvláštním významem“ napříč různými sociálně-vědnými disciplínami, které migraci tematizují. Postupuje přitom od politicko-demografických ke kritickým diskurzům migrace. V první části 
představuje vedle současných statistik světové migrace terminologii, která se v politice a vědě používá pro označení migrujících osob. Statistiky nepř́ímo odkrývají mnohé sféry problematizace migrace, kterými se zabývají různé sociálně-vědné disciplíny, stejně jako státní a mezinárodní politické a hospodářské instituce a zainteresovaní představitelé občanské společnosti, včetně médií. Text se dále soustředí na relevantní sociálně-vědná paradigmata migrace s přihlédnutím k problematice její politické regulace, která je při přemýšlení o moderní migraci neopomenutelná. Jsou zde představena třídící hlediska, která lze na migrační teorie a koncepty aplikovat, stejně jako různé způsoby, jakými se sociální vědy s fenoménem migrace vyrovnávají. Text, byt' přehledový, není zcela hodnotově neutrální. K migraci přistupuji spíše jako k intelektuální výzvě promýšlet současné společenské podmínky moderních post-industriálních společností, než jako k problému, který má být jednou a provždy vyř̌š̌en. Právě neexistence snadných řešení činí moderní migraci přitažlivou; bohužel také pro ideology orientující se na nabídky snadných řešení.

\section{I.}

Stěhování lidí nabývá v moderních podmínkách zvláštního významu. Svět je hranicemi geopoliticky rozparcelován na státy, které jsou zároveň nacionálně definovanými pomyslnými společenstvími (Anderson 1983 [1991]). Existence státních hranic v moderním smyslu slova umožňuje vnímat jejich překračování jako významotvorný akt. Takové stěhování se zvláštním významem jsme uvykli nazývat migrací. Dnes je pojem migrace pevně ukotven v diskurzu politické organizace světa - mimo jiné definicí OSN, která ho pojímá jako delší než jednoroční pobyt jedince za hranicemi státu, v němž se narodil. Touto definicí se utvrzuje vnímání migrace jako abnormální situace, vybočení z přirozeného stavu, v němž lidé žijí ve státech, ve kterých se narodili. To ještě posiluje rozlišování migrace a mobility - druhý pojem označuje favorizovaný vnitřní pohyb členů státního či mezinárodního společenství za účelem zvyšování hospodářské produktivity. Evropská komise vyhlásila rok 2006 rokem propagujícím mobilitu pracovníků, jako by Evropa zapomněla na slavný citát švýcarského prozaika Maxe Frische „Pozvali jsme pracovníky, ale přišli lidé“, který naznačuje problematičnost selektivních popudů ke stěhování za účelem rozmachu odehrávajícího se na trhu práce.

Migrace souvisí nejen s politickou, ale také s ekonomickou a sociálně-kulturní regulací pohybu mezi státy a ve „věku migrace“ (Castles a Miller 1998) také stále více s podmínkami pobývání na státním teritoriu. Zkušenosti s migrací po 2 . světové válce jsou významně ovlivněny ropnou krizí v roce 1973 a událostmi, které v západní Evropě následovaly. Dělníci, kteří byli přizváni $\mathrm{k}$ rekonstrukci Evropy v rámci Marshallova plánu, se náhle stali konkurenty na omezeném trhu práce a $\mathrm{k}$ překvapení tvůrců migračních politik se po odeznění pracovních př́ležitostí hromadně nenavrátili do ekonomicky méně bohatých částí světa, odkud prrišli. S klesající zaměstnaností přistěhovalců se zviditelňoval problém etnicky definované ghetoizace a integrace Druhého, legitimity sociálního státu a mechanismů sociálního vyloučení. Obdobný jev socio-ekonomické diskontinuity můžeme pozorovat v České republice po roce 1989, kdy důsledky restrukturalizace trhu práce dopadly na námezdní dělníky z řad slovenských Romů, kteří se po 2. světové válce do určité míry organizovaně přesunuli do České republiky, aby zde pracovali v těžkém průmyslu. 
Teoretické diskuse o migraci v post-industriální době odehrávající se v posledních letech v Evropě a Severní Americe jsou provázané s diskusemi o destabilizaci implicitních podpůrných norem společností národních států, které se spolu s normativním a nezpochybnitelným vnímáním organizace světa podle logiky těchto moderních národních států, zdá se, poněkud přežily.

Jako migrace bývá v politice i v sociálních vědách souhrnně označována (dobrovolná) migrace, stejně jako migrace nucená - uprchlictví. Tuto dvojznačnost pojmu migrace zachovávám - někdy znamená pouze dobrovolné stěhování a někdy bez rozlišení jak toto dobrovolné stěhování, tak uprchlictví. Tam, kde je to důležité, je z kontextu patrné, který význam pojmu migrace zde mám na mysli. $\mathrm{V}$ sociálně-vědných diskusích o migraci představuje rozdíl mezi dobrovolnou a nucenou migrací, z hlediska politické regulace migrace zásadní, pouze jednu $\mathrm{z}$ většího množství důležitých charakteristik situace migrujícího. Na druhé straně některé aspekty ze sociálně-vědného hlediska zásadní jsou v jazyce politické regulace migrace opomíjeny. Citlivost $\mathrm{k}$ genderově definovaných rozdílům, která je ze sociálně-vědného hlediska zásadní, se v zaužívaném termínu „migrant“ vytrácí. Genderové hledisko jsem se snažila reflektovat alespoň terminologicky. Namísto neobratného migrant/migrantka používám všude tam, kde je to stylisticky schůdné, obojetný výraz „migrující“. Podobně hraje pro pochopení zkušenosti migrace velmi důležitou, jazykově však nesnadno vyjádřitelnou, úlohu věk, respektive pozice v životním běhu migrující-ho. Alespoň tedy na úvod zmiňuji, že hovoříme-li o migraci a migrujících, zdaleka se vždy nejedná o dospělé lidi v produktivním věku.

\section{II.}

Pro migraci v moderním smyslu slova vytváŕí rámec politická regulace pohybu lidí za hranice národních států. V roce 1951 byla OSN v Ženevě přijata úmluva o právním postavení uprchlíků známá jako Ženevská konvence, která v Článku 1 ustanovila definici uprchlíka a uložila povinnost národním státům, jež Úmluvu přijmou, aby v př́ípadě uprchlíků, kteří se na jejich území ocitli před 1. lednem 1951, dbali na dodržování jejich lidských práv (Úmluva 1951). Důležitým bodem Úmluvy je také povinnost států neiniciovat návrat uprchlíka do země původu, dokud nepomine hrozba porušování lidských práv v zemi, odkud pochází. V roce 1967 byl pak k Úmluvě přidán protokol, který ruší platnost pouze těch žádostí o azyl, jež by odkazovaly k událostem, které se staly před 1. lednem 1951 (Protokol 1967). Andreas Demuth shrnuje důvody vedoucí $\mathrm{k}$ nucenému a dobrovolnému migrování a útěku v následujícím přehledovém schématu.

Př́značné je, že narozdíl od důvodů umožňujících poskytnutí azylu se na typologii dobrovolné migrace mezinárodní společenství zatím nedokázalo dohodnout, i když jisté standardizační pokusy existují - představují je především ekonomické teorie migrace (Massey a kol. 1993). Hranice mezi nucenou a dobrovolnou migrací se navíc stále více relativizuje. Proměnou prochází také instituce azylu - v legislativě Evropské unie je od roku 2004 zakotvena jako legitimní důvod žádosti o azyl také př́slušnost k pohlaví (Směrnice 2004). Od záŕí roku 2006 je tato právní praxe aplikována v České republice.

Narozdíl od uprchlictví, tedy násilné migrace, byla úprava dobrovolné migrace dlouho záležitostí jednotlivých národních států, a v těchto úpravách se proto zrcadlí hospodářsko-politické zájmy toho kterého státu, stejně jako implicitní normy a hodnoty společností 
Schéma 1: Rozdělení migrace na dobrovolnou a nucenou

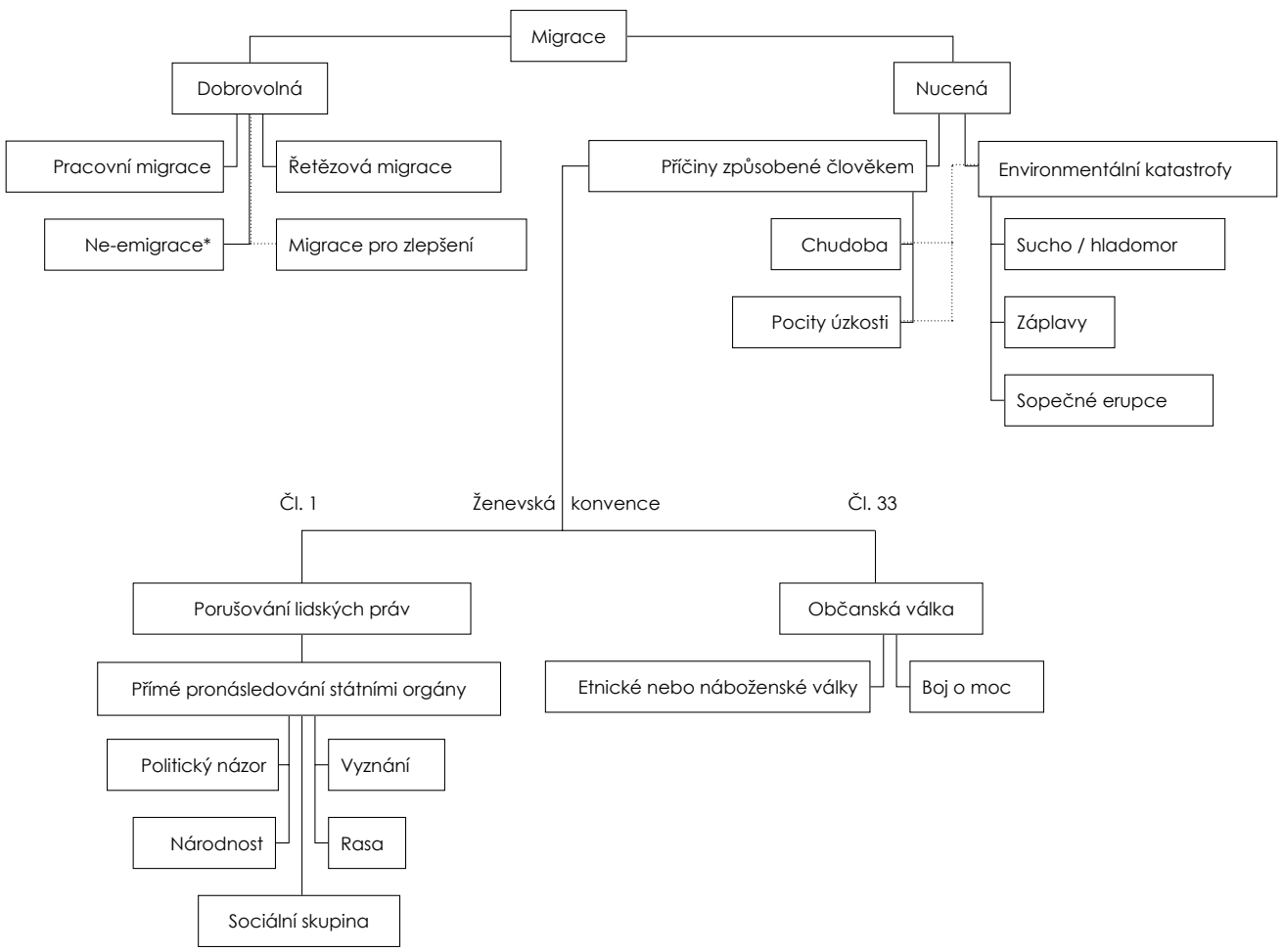

* Pracovní a studijní pobyty.

Zdroj: Demuth (2000: 38).

národních států. To je zvlášt' viditelné na mechanismech naturalizace - udělování občanství. Mechanismy naturalizace však mohou být naopak pozměněny na základě migračních událostí. V Evropě nabyla diskuse o migraci na intenzitě v souvislostí se světovou ropnou krizí v roce 1973. Země, které po druhé světové válce hojně přijímaly sezónní dělníky, musely náhle čelit rostoucí nezaměstnanosti „domácích“ obyvatel. Sezónní dělníky se ovšem nedařilo prostě poslat zpět. Naopak. Například v Německu začalo být stále jasnější, že turečtí ,gastarbeitřii“ se stávají něčím jiným než dočasnou pracovní silou. Začali četně využívat nároku na znovu-sloučení rodiny imigrující-ho a realizací rodinného života zviditelnili otázku občanských nároků imigrantů. Teprve o několik desetiletí později nabyl způsob udělování občanství v Německu také podoby ius soli.

V diskurzu politické regulace migrace je terminologie migrace určována dvěma podmínkami: tím, zda došlo k překročení hranic národního státu a zda se jedná o dobrovolné, nebo nucené stěhování. Z toho vyplývá soubor označení těch, kteří jsou nositeli fenoménu moderního migrování. 
Tabulka 1: Přehled politických označení migrujících

\begin{tabular}{|c|c|c|c|}
\hline & Dobrovolná & \multicolumn{2}{|l|}{ Nucená } \\
\hline V rámci národního státu & $\begin{array}{l}\text { Vnitřní migrant } \\
\text { Dojíždějící za prací }\end{array}$ & \multicolumn{2}{|c|}{$\begin{array}{l}\text { Vnitřní vysídlenec (Internally } \\
\text { Displaced Person) }\end{array}$} \\
\hline \multirow[t]{3}{*}{ Přes hranice národního státu } & \begin{tabular}{|l|} 
Migrant \\
Imigrant \\
Emigrant \\
Nelegální imigrant \\
Imigrant bez dokladı̊ \\
(undocumented) \\
Ekonomický migrant
\end{tabular} & $\begin{array}{l}\text { Žadatel o azyl } \\
\text { Uprchlík }\end{array}$ & \\
\hline & & $\begin{array}{l}\text { Falešný uprchlík (bogus refugee/ } \\
\text { asylum seeker) }\end{array}$ & \\
\hline & Transmigrant & & \\
\hline
\end{tabular}

V posledních letech se vynořují termíny, které jednoznačné kategorie „uprchlík“ a „migrant“ relativizují. Patří k nim pojmy „falešný uprchlík“ a „transmigrant“. Pojem falešný uprchlik destabilizuje hranici mezi dobrovolnou a nucenou migrací, která je v období globalizace hospodářství a komunikace stále méně evidentní. Toto označení se stále více používá od 90. let 20. století a zpochybňuje legitimitu žádostí o azyl lidí pocházejících z oblastí, které nejsou jednoznačně vnímány jako život ohrožující a zároveň naznačuje ekonomický zájem azylanta. Termín ,falešný uprchlík“ deklaruje spíše než podstatu statusu nositele tohoto označení to, kým onen jedinec z právního hlediska není, nebo tak docela není. Vztahuje se na situace, $v$ níž lidé z relativně ekonomicky rozvinutých zemí a poklidných politických poměrů žádají o politický azyl. Toto označení popisuje situaci, kdy je těžké rozlišit mezi ekonomicky motivovanou migrací a politicky motivovaným útěkem (Castles a Miller 1998: 29). Tato forma migrace je př́značná pro migraci Romů z postkomunistických zemí na Západ v 90. letech 20. století. Vyznačuje se vysokou mírou legality a nízkou mírou legitimity. Označení těchto žadatelů za „falešné“ uprchlíky de facto znamená, že jejich útrapy nejsou uznány jako dostatečné, a obviňuje je ze zneužívání sociálního systému (Dummett 2001: 44). Západoevropské a severoamerické migrační politiky a praxe umožňovaly získat politický azyl lidem z formálně demokratických zemí, což bylo pro aparáty státní správy matoucí. V řadě postkomunistických zemí se situace změnila vstupem do Evropské unie, čímž zájemci pozbyli právo žádat o politický azyl v zemích Evropské unie.

Pojem transmigrant pak rozmělňuje neměnnost a jednoznačnost dvou bodů migračního vektoru směřujícího ze země původu do cílové země a upozorňuje na nemožnost usazení rozpohybovaných mas lidí do domácích a imigrantských komunit, což relativizuje rozparcelování světa na fyzicky exkluzivní státní útvary. Transmigranti jsou migranti, kteří se zabydlují ve „třetím“ prostoru transnacionálních sítí (Barša a Baršová 2005: 8). Souřadnice země původu - cílová země zcela nevystihují jejich životní prostor, nebot' jejich primární sociální sít' je často rozprostřena naprŕíc těmito zeměmi; tyto osoby jsou často ,doma“ ve více než dvou státech. Potomci slovenských Romů, kteří prrišli v 50. letech do České republiky a jejichž příbuzní nyní žijí v České republice, Kanadě, Irsku a na Slovensku, mohou být př́íkladem takové transnacionální sítě. Jednou přijedou „Kanad'ané“ pokřtít své dítě do Evropy a ostatní na 
událost přicestují ze svých aktuálních domovů v České republice a na Slovensku, podruhé „českác babička navštíví na půl roku rodinu v Kanadě (Výzkum 2004). Téma transnacionalismu otevírá otázky duálního občanství, sociální struktury globalizovaného světa, stejně jako se stalo novou výzvou pro pojetí sociálně-vědného výzkumu migrace (Vertovec 2004).

\section{III.}

Jak vypadá současná světová demografická bilance migrace? Statistiky OSN definují migranta jako člověka, který žije mimo své rodiště. Rozlišují přitom migranty a uprchlíky a v celosvětovém měřítku rozdělují státy do tří oblastí podle míry jejich rozvinutosti (OSN 2006). Jako více rozvinuté země jsou označeny Evropa, Severní Amerika, Austrálie, Nový Zéland a Japonsko. Méně rozvinuté země zahrnují všechny oblasti Afriky, Latinské Ameriky, Karibiku a Asie mimo Japonsko a jmenovitý výčet nejméně rozvinutých zemí, dále oblasti Melanésie, Mikronésie a Polynésie. Jako nejméně rozvinuté země označuje OSN padesát zemí od Afghánistánu po Zambii.

Tabulka 2: Poměr zaznamenaných migrujících ve světové populaci (OSN 2006)*

\begin{tabular}{|c|c|c|c|c|c|c|c|c|}
\hline & 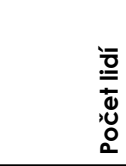 & 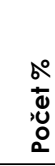 & 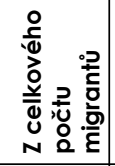 & 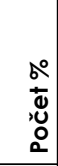 & 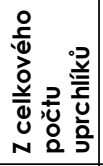 & 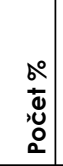 & 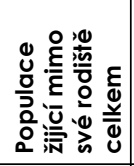 & $\begin{array}{l}\swarrow 0 \\
\bar{d} \\
\mathbf{d} \\
0 \\
0\end{array}$ \\
\hline $\begin{array}{r}\text { Světová } \\
\text { populace }\end{array}$ & 6464750 & 100 & 177165 & 2,7 & 13469 & 0,2 & 190634 & 2,9 \\
\hline $\begin{array}{l}\text { Nejméně } \\
\text { rozvinuté oblasti }\end{array}$ & 759389 & 11 & 8055 & 1,1 & 2405 & 0,3 & 10460 & 1,4 \\
\hline $\begin{array}{r}\text { Méně rozvinuté } \\
\text { oblasti }\end{array}$ & 5253484 & 72 & 64469 & 1,2 & 10768 & 0,2 & 75237 & 1,4 \\
\hline $\begin{array}{r}\text { Více rozvinuté } \\
\text { oblasti }\end{array}$ & 1211265 & 17 & 112696 & 9,3 & 2701 & 0,2 & 115397 & 9,5 \\
\hline
\end{tabular}

* Počty lidí jsou v tisících.

Spíše než absolutními počty migrantů je statistika OSN zajímavá poměry migrantů a uprchlíků v oblastech podle rozvinutosti. Země ve více rozvinutých oblastech nepřijímají navzdory svému ekonomickému a politickému privilegovanému postavení více uprchlíků než ostatní. $\mathrm{V}$ absolutních počtech přijímají bezkonkurenčně nejvíce uprchlíků méně rozvinuté oblasti. Na druhou stranu na území států více rozvinutých oblastí pobývá absolutně i relativně nejvíce migrantů - téměř každý desátý člověk se zde nenarodil v zemi, v níž aktuálně žije, navíc sociálně jsou v pozici přistěhovalců také potomci imigrantů.

Statistiky OSN pojednávající o světové migraci neobsahují dvě důležité kategorie - jsou to vnitřní vysídlenci a ilegální imigranti. Prvně jmenovaní jsou doménou méně a nejméně rozvinutého světa, ti druzí pak více rozvinutých oblastí.

Vnitřní vysidlenci (internally displaced people) jsou nuceni z důvodů občanské války či environmentální katastrofy opustit své domovy, ale z administrativního hlediska setrvávají na území státu, v němž se narodili. Tyto osoby se až na oblasti bývalého Sovětského svazu a bývalé 
Jugoslávské federace vyskytují pouze v méně a nejméně rozvinutých oblastech světa. Ze 70 až 80 procent je tvoří ženy a děti (IDMC 2006). V roce 2005 bylo na světě 23700000 vnitřních vysídlenců, z toho 2800000 v Evropě a 20900000 v méně a nejméně rozvinutých oblastech světa.

Imigranti bez dokladi̊, respektive ilegální imigranti, tvoří nemalou část společností rozvinutých oblastí. Na počátku 90 . let byl jejich počet odhadován na $3500000-5500000$ v západní Evropě a stejný počet v USA (Drbohlav 2003). Počet imigrantů bez dokladů/ilegálních imigrantů neklesá a dnes jsou tito lidé již integrální součástí také středoevropských společností. Jen Ukrajinců s dlouhodobým nebo trvalým pobytem bylo v České republice k 31. 12. 2005 registrováno 87789 (Český statistický úrad 2005).

Uvedené statistické výčty naznačují, že pro více rozvinuté oblasti, kde se intenzivně diskutuje nad migračními politikami stejně jako nad způsoby výzkumu migrace, představuje přes-hraniční migrace podstatný a viditelný společenský jev. Normativní předpoklady fungování moderních států jsou pouhou př́tomností množství rodin, které praktikují odlišné způsoby vaření a socializace svých potomků, stejně jako lidí, jejichž mateřský jazyk není oficiálním jazykem státu, v němž žijí, stavěny před nové výzvy reflexe a snad reformulace principů, na nichž stojí. V letech 1965-2000 se počet imigrantů prudce zvýšil (Martin a Windgren 2002) a zdá se, že moderní státní instituce stejně jako implicitní dominantní zvyklosti chování ve veřejném prostoru nejsou připraveny účinky novodobého migrování efektivně vstřebat.

\section{IV.}

Od dob Kuhnovy Struktury vědeckých revoluci (1962, česky 1997) se v sociálních vědách ustálilo odlišování fenoménu od konceptů, které jej popisují. Imperativ reflexe, důraz kladený na vědomí této dvojakosti sociálního světa je zvláště naléhavý v prŕípadě fenoménů se silnou politickou konotací, jakými jsou všechny otázky dotýkající se problematiky národních států a nacionalismu (Hobsbawm 2000). Giddens principem dvojí hermeneutiky (1976) pojmenoval vzájemnou interakci konceptů a fenoménů - oboustranné působení všednodenního života a expertního vědění. Migrace takové působení dobře demonstruje. Migrující mění směr svého pohybu s ohledem na změny v podmínkách imigrace, které státy nastavují. Na druhou stranu, expertní koncepty migrace se snaží zpětně vysvětlit neočekávané migrační události související s migrováním. Někdy jsou fenomény o krok napřed před koncepty a regulujícími institucemi (př́íladem toho jsou chaotické reakce na romské imigranty z postkomunistických zemí na Západě), jindy je životní strategie rodiny významně ovlivňována institucionálním ukotvením členů rodiny v místě bydliště. Původně dočasní imigranti zůstávají tam, kam prrišli, na dlouhá léta berouce v potaz to, že jejich dítě nastoupí do místní základní školy (Výzkum 2006). Možnosti sociální pomoci i uplatnění na trhu práce se dramaticky liší pro registrované občany, prisstěhovalce se statusem trvalého pobytu, legální príistěhovalce bez něj a pro přistěhovalce bez dokladů (Mateos 2000, Čaněk a kol. 2006).

Přehled sociálně-vědných teorií a konceptů migrace by dnes již vydal na několikasvazkovou encyklopedii. Každý přehled konceptů migrace reflektuje jak metodologickou rozmanitost výzkumů migrace a z ní vyplývající omezení poznávacích možností, tak zájmový/ politický rozměr jednotlivých konceptů a metod. Takový přehled dobře poslouží jako orientace v sociálně-vědných tradicích, obeznámenost s ním však nezaručuje úspěšnost provedeného výzkumu. Douglas Massey a kol. (1994: 700) kritizují př́lišnou zaujatost severoamerických 
výzkumů migrace metodologií a problémy měření, která neprospívá teoretickému porozumění tomuto fenoménu. Cílem následujícího souhrnu je podívat se na teorie a koncepty migrace ze čtyř základních hledisek: 1 . Zda je jejich analytický postup konvenční, nebo kritický (nikoliv kritizující) vzhledem k politickému diskurzu migrace; 2. jakou úroveň analýzy/měřítko pohledu preferují; 3. který moment v události migrace je středem jejich zájmu; a konečně 4 . která vědecká disciplinární tradice je pro ně základní.

Konvenční přistup $k$ analýze migrace znamená, že autoři přejímají terminologii práva a politiky a popisují pak množství a vlastnosti lidí, na něž lze aplikovat zařazení do jednotlivých kategorií migrace. Příkladem jsou geografické výzkumy migračních toků, které bývají znázorňovány jako šipky na mapách, jejichž tloušt'ka odpovídá množství migrujících (např. Castels a Miller 1998). Z konvenčního geografického pojetí analýzy migrace pochází také termín „tranzitní země“ označující oblasti, kterými migrující „pouze procházejí“. Další typickou konvenční analytickou disciplínou je demografie. Statistiky migrace přejímají koncept (jednoho) státu původu a (jednoho) státu aktuálního pobytu migranta jako základního nástroje demografické analýzy migrování. Existují však také alternativní geografické koncepty místa a migrace, v rámci nichž mohou vznikat empirické studie pracující s četnostmi výskytu (např. McHugh a kol. 1995). Druhou tendenci zkoumání představují kriticky analytické studie migrace. Vedle snahy osvětlit existenci jevů, které s migrací souvisejí, ale nejsou zcela pojmenovatelné termíny politické regulace migrace, podrobují takto orientované studie kritické analýze samotné tyto termíny, jejich vznik, použití a proměnu v čase. Ke kritickým analytikům migrace lze také počítat autory, kteří svými texty zasahují na pole filosofie sociálních věd. Někteří myslitelé považují „bytí v přesunu“ za důležitý až přirozený stav společenské existence, stejně jako stav mysli současného (pozdně moderního) člověka. Např́klad Angelika Bammer mluví o fenoménu vymístění, a to bud' ve smyslu fyzického odloučení člověka od jeho rodné kultury, nebo jako o kolonizaci jinou kulturou, jako o základní zkušenosti současného člověka (1994). Rozdíl mezi konvenčně a kriticky analytickým př́stupem není v badatelské praxi absolutní. Jak upozorn̆ují Rabušic s Burjankem (2002), již klasik konvenčního geografického př́stupu E. S. Lee (1966), který navázal na proslulou Ravensteinovu stat' The Laws of Migration (1898), přiznával jistou závislost potenciálu migrovat na aktuální individuální situaci lidí. Uvědomění si rozdílu mezi konvenčním a kritickým př́istupem $\mathrm{k}$ migraci však může pomoci v paradigmatické orientaci $\mathrm{v}$ teoriích migrace.

Migraci lze zkoumat $\mathrm{v}$ různém měřítku, od individuálních pohnutek a subjektivního prožívání přes rodinné sítě a životní strategie domácností, hledisko etnických a kulturních skupin, národních států a institucí, až po mezinárodní vztahy a globální světový systém. Demuth (2000) rozlišuje při zkoumání migrace mikrorovinu zaměřenou na migrující jedince a makrorovinu zaměřenou na společnost ve smyslu řešení negativních dopadů migrace jedinců. To odpovídá $\mathrm{v}$ migrační politice $\mathrm{i} v$ sociálních vědách často př́tomnému předpokladu, že zájmy migrující-ho mohou být $\mathrm{v}$ rozporu se zájmy at' již státu, z něhož daná osoba odešla (např́klad brain-drain - odliv kvalifikovaných občanů), nebo státu, kam migruje (např́klad ilegální přistěhovalectví nebo náklady na azylovou proceduru žadatelů). Faist (1997) oproti tomu pojmenovává tři úrovně analýzy. Je to individuální mikrorovina zkoumající stupně svobody těch, kteří jsou potenciálně v pohybu, vztahová mezoro- 
vina zaměřující se na sociální vazby mezi těmi, kteří jsou v pohybu, a těmi, kteří zůstávají, a konečně strukturální makrorovina, která se zabývá politicko-ekonomickými a kulturními faktory migrace $\mathrm{v}$ zemích původu a cílových zemích. Měřítku pohledu nutně neodpovídá míra zobecnění výsledků výzkumu. Například, teorie migračních vzorců hledá všeobecné zákonitosti v pohnutkách a pohybu migrujících lidí, zatímco historiografická práce může popisovat imigrační mezinárodní právní úmluvu, aniž by usilovala o jakoukoliv abstrakci. Rozlišování úrovní analýzy je metodologickou pomůckou, která pomáhá udržovat konzistentní teoretické zázemí při př́ípravě výzkumu, volit výzkumnou strategii, stejně jako interpretovat zjištěné skutečnosti. Pro jednotlivé sociálně-vědné disciplíny jsou také typická určitá měř́tka pohledu, přestože se ve snaze učinit praxi sociální vědy interdisciplinární tyto typizace stále více vytrácejí. Spolu s voláním po interdisciplinaritě tak dochází k pokusům o víceúrovňovou analýzu migrace (např́ílad Brettell 2003, Morawska 2003). V praxi migrace se všechny vrstvy sociální skutečnosti projevují paralelně a vzájemně na sebe působí.

Proces migrování je možno rozdělit do několika časově následujících fází. Demuth (2000) hovoří o čtyřech fázích migrace a o dvou, které s těmito fázemi úzce souvisejí. Jsou to a) rozhodování o migraci, 1. odchod, 2. cesta, 3. příchod, 4. pobyt; a b) zabydlování se. Demuth považuje migraci za individuální akt, $\mathrm{k}$ němuž může rodina a sociální prostředí vytvářet jeden z kontextů, přičemž každá fáze migrování jedince má specifický kontext, který je při výzkumu nutno vzít v potaz. Některé koncepty migrace naopak za centrální jednotku analýzy migrace považují rodinu (např. Orellana a kol. 2001). Do jisté míry lze pozorovat přesun ke komplexnějšímu zkoumání životních podmínek migrujících s tím, jak se v 70. a 80. letech $\mathrm{k}$ mužům $\mathrm{v}$ aktivním věku, kteří prrišli za prací, začaly přidávat ženy a děti. Böhning (1984 podle Castles a Miller 1998: 28) rozlišuje ve svém modelu čtyř stádií migrace stádia dočasné pracovní migrace mladých pracovníků, prodloužení pobytu a vytváření sociálních sítí, opětovného setkání rodiny a permanentního usazení se. Zatímco ekonomicky orientované teorie migrace se častěji snaží zodpovědět otázku motivu k migrování a zabývají se tak počátečními fázemi migračního procesu, sociologické a antropologické studie se zaměřují na kontext migračního procesu a na každodenní životní podmínky imigrantů v pozdějších fázích migračního procesu.

Existuje mnoho způsobů hodnocení sociálně-vědných disciplín zabývajících se migrací. Barša a Baršová (2005) v prvním dodatku své knihy Přistěhovalectví a liberální stát představují hlavní teorie migrace, o nichž píší Douglas Massey a kol. (1993).

Zatímco ekonomické výklady migrace si konkurují, ostatní teorie jsou kompatibilní - doplňují ekonomický pohled na migraci, stejně jako se mohou doplňovat navzájem. Ne všechny disciplíny přinášejí „velké“ teorie migrace, přesto svými výzkumy a z nich vyvozenými koncepty významně přispívají $\mathrm{k}$ vědění o migraci. Když Caroline $\mathrm{B}$. Brettell a James F. Hollifield strukturovali svou knihu Migration Theory. Talking Across Disciplines (2000) ${ }^{1}$, rozhodli se pro podobu separovaných statí představujících př́stup k migraci v rámci jednotlivých relevantních sociálně-vědných oborů. S odkazem na Alejandro Portese (1997) prosazují představu, že není reálné vytvořit jednu ucelenou teorii migrace, která by zohledňo-

\footnotetext{
${ }^{1}$ Kniha vznikla na základě setkání Social Science History Association.
} 
Tabulka 3: Hlavní teorie migrace podle Massey a kol. (1993) komentované Baršou a Baršovou (2005)

\begin{tabular}{|c|c|c|}
\hline $\begin{array}{l}\text { Neoklasická teorie } \\
\text { Nová ekonomie } \\
\text { Teorie segmentovaného } \\
\text { pracovního trhu } \\
\text { Teorie světosystému }\end{array}$ & Teorie migračních systémů & $\begin{array}{l}\text { Klientská politika } \\
\text { a „antipopulistická norma“ } \\
\text { Kumulativní př́čina } \\
\text { a institucionalismus } \\
\text { Teorie migračních sítí } \\
\text { a transnacionálního prostoru }\end{array}$ \\
\hline \multicolumn{2}{|l|}{ VYSVĚTLENÍ příčin a původu migrace } & POPIS způsobu produkce a reprodukce migrace \\
\hline $\begin{array}{l}\text { Ekonomické teorie } \\
\text { (makroekonomie a behaviorální } \\
\text { ekonomie) } \\
\text { Konkurenční }\end{array}$ & $\begin{array}{l}\text { Doplnění ekonomických teorií } \\
\text { Kompatibilní s ekonomickými } \\
\text { i neekonomickými teoriemi }\end{array}$ & $\begin{array}{l}\text { Neekonomické sociálně-vědné } \\
\text { teorie } \\
\text { Kompatibilní s ostatními teoriemi } \\
\text { i navzájem }\end{array}$ \\
\hline
\end{tabular}

vala všechny aspekty migrování. Brettell a Hollifield vybrali jako relevantní sociální vědy antropologii, demografii, ekonomii, historii, politologii, právo a sociologii. Pro český kontext je zajímavé u nás ne zcela obvyklé odlišení demografie od sociologie a antropologie, stejně jako připisování postupů oral history spíše historii než sociologii/antropologii. Autoři přinášejí přehled výzkumných otázek, úrovní analýzy, dominantních teorií a výzkumných hypotéz, které jednotlivé vědní obory odlišují. Pro účely této stati jsem v tabulce migračních teorií a konceptů podle disciplín zachovala informaci o úrovni analýzy a také vzorové hypotézy. Všechna doplnění nad rámec přehledu Brettell a Hollifielda jsou vyznačena italikou. Přidávám vztah k politické terminologii migrace a fáze migrace, které jsou tou kterou disciplínou nejčastěji sledovány. $\mathrm{V}$ původním přehledu chybí sociální geografie, disciplína tradičně zpracovávající téma migrace, a také psychologie (Bhugra 2004). V sociální geografii je možno v posledních letech sledovat rozšiřování paradigmatického zázemí o konstruktivistické přístupy, v předkládaném přehledu se držím spíše konvenčního zaměření a dopouštím se tak schematičnosti za účelem podání informativního přehledu. Přidávám ještě obecnou filosofii sociálních věd ve smyslu epistemologického bádání po původu a podmínkách vědeckého chápání migrace.

Intenzivní bádání v oblasti hledání příčin odchodu imigrantů do rozvinutých zemí, kam z celosvětového hlediska patří také Česká republika, se často realizuje za účelem omezení pohybu lidí „na západ a na sever“ (Demuth 2000). Od 70. let, kdy ekonomicky rozvinutá část světa zaznamenala ropnou krizi, jsou státy s rozvinutou ekonomikou citlivější na vstup lidí z jiných zemí na své území a tyto tlaky se zintenzivňují s událostmi mezinárodního terorismu (viz text José Casanovy v tomto čísle Sociálních studii). Přestože většina těch, kteří se snaží krátko-či dlouhodobě usadit v zemích s rozvinutou ekonomikou a demokratickým zřízením, nejsou ani teroristé, ani původci náznaků hospodářské krize těchto zemí, snahy místních politiků omezovat mezinárodní imigraci jsou patrné a sílí. Vedle etické spornosti studia prŕčin migrace za účelem jejich odstranění, nebot' regulační politiky migrace většinou smršt'ují lidské jedince na pracovní sílu a jako chtěné pak definují pouze ty kvalifikované, jsou studia prŕíčn migrace omezená ve svých výsledcích. Existuje mnoho lidí, kteří žijí ve velmi špatných podmínkách a přesto neemigrují. Na jedinci nezávislé vlastnosti prostředí, jako minimální mzda, vymahatelnost práva, či subjektivně pocitovaná bezpečnost na veřejných místech se totiž v procesu rozhodování o migraci konfrontují a kombinují s vlastnostmi primárního sociálního prostředí, jako jsou vztahy v rodině a přátelské vazby, představy o dobrém životě a o možnostech realizovat své životní 
Tabulka 4: Migrační teorie a koncepty v sociálně-vědných disciplínách

\begin{tabular}{|c|c|c|c|c|}
\hline Disciplína & $\begin{array}{l}\text { Vztah analýzy } \\
\text { k politické } \\
\text { terminologii } \\
\text { migrace } \\
\end{array}$ & Úroveň analýzy & $\begin{array}{l}\text { Analyzovaná fáze } \\
\text { migrace }\end{array}$ & Vzorová hypotéza \\
\hline Antropologie & Kritická & $\begin{array}{l}\text { Spíše mikro/jedinci, } \\
\text { domácnosti, skupiny }\end{array}$ & Všechny fáze & $\begin{array}{l}\text { Sociální sítě } \\
\text { pomáhají udržovat } \\
\text { kulturní odlišnost }\end{array}$ \\
\hline Demografie & Konvenční & $\begin{array}{l}\text { Spiše makro/ } \\
\text { populace }\end{array}$ & Odchod, príchod & $\begin{array}{l}\text { Imigrace zvyšuje } \\
\text { porodnost }\end{array}$ \\
\hline Ekonomie & Konvenční & Spiše mikro/jedinci & $\begin{array}{l}\text { Rozhodování } \\
\text { se, odchod, } \\
\text { ekonomická stránka } \\
\text { zabydlování se }\end{array}$ & $\begin{array}{l}\text { Úspěšné začlenění } \\
\text { do společnosti } \\
\text { (incorporation) } \\
\text { záleží na lidském } \\
\text { kapitálu migrujících }\end{array}$ \\
\hline Historie & Konvenční i kritická & $\begin{array}{l}\text { Spiše mikro/jedinci } \\
\text { a skupiny }\end{array}$ & $\begin{array}{l}\text { Odchod, } \\
\text { cesta, pobyt } \\
\text { a zabydlování se }\end{array}$ & Není aplikovatelné \\
\hline Právo & Konvenční & $\begin{array}{l}\text { Makro a mikro/ } \\
\text { politický a právní } \\
\text { systém }\end{array}$ & $\begin{array}{l}\text { Odchod, příchod, } \\
\text { pobyt }\end{array}$ & \begin{tabular}{|l|} 
Právní opatření \\
vytvářejí stimulující \\
struktury pro \\
migrující \\
\end{tabular} \\
\hline Politologie & Konvenční & $\begin{array}{l}\text { Spiše makro/ } \\
\text { politické } \\
\text { a mezinárodní } \\
\text { systémy }\end{array}$ & $\begin{array}{l}\text { Odchod, příchod, } \\
\text { pobyt }\end{array}$ & \begin{tabular}{|l|} 
Státy jsou často \\
svazovány \\
pro-imigrantskými \\
zájmy
\end{tabular} \\
\hline Sociologie & Konvenční i kritická & $\begin{array}{l}\text { Spiše makro/etnické } \\
\text { skupiny a sociální } \\
\text { třídy }\end{array}$ & $\begin{array}{l}\text { Rozhodování } \\
\text { o migraci, odchod, } \\
\text { příchod, pobyt, } \\
\text { zabydlování se }\end{array}$ & $\begin{array}{l}\text { Úspěšné začlenění } \\
\text { do společnosti } \\
\text { (incorporation) } \\
\text { imigranta záleží na } \\
\text { sociálním kapitálu }\end{array}$ \\
\hline $\begin{array}{l}\text { Filosofie sociálních } \\
\text { věd }\end{array}$ & Kritická & Není aplikovatelné. & Všechny fáze & $\begin{array}{l}\text { Způsob, jakým } \\
\text { artikulujeme } \\
\text { a chápeme } \\
\text { migraci, je ukotven } \\
\text { ve stávajícím řádu } \\
\text { vědění a zkušeností }\end{array}$ \\
\hline Psychologie & Konvenční & $\begin{array}{l}\text { Spiše mikro/jedinec } \\
\text { a skupina }\end{array}$ & $\begin{array}{l}\text { Příchod, pobyt, } \\
\text { zabydlování se }\end{array}$ & $\begin{array}{l}\text { Zkušenost migrace } \\
\text { je destabilizující } \\
\text { a vyvolává potřebu } \\
\text { psychickému } \\
\text { zvládnutí }\end{array}$ \\
\hline Sociální geografie & Konvenční & $\begin{array}{l}\text { Makro i mikro/ } \\
\text { národní státy, } \\
\text { kontinenty, jedinci } \\
\text { v prostory }\end{array}$ & $\begin{array}{l}\text { Odchod, cesta, } \\
\text { príchod }\end{array}$ & $\begin{array}{l}\text { V migraci můžeme } \\
\text { pozorovat } \\
\text { prostorové } \\
\text { zákonitosti } \\
\end{array}$ \\
\hline
\end{tabular}

Zdroj: Brettell a Hollifield 2000: 3.V.

plány a sny. To, zda se člověk vydá cestou migrace nebo ne, se rozhoduje v rozmanitých a často neplánovaných situacích a kontextech. Mnoho migrujících se také nedá zcela bezvýhradně zařadit do žádné z právně definovaných kategorií.

Mnohé konceptualizace migrace jsou určovány strukturou, institucemi a potřebami národních států, které jsou spjaty s procesem modernizace a změnami hospodaření, kultury i životního stylu. Migrace není moderním fenoménem pouze tím, že je byrokraticky spravová- 
na v nacionálně a státně definovaných prostorech. Mnoho lidí míří do měst za vidinou výdělku a jejich životní styl se životem ve městech proměňuje. S imigrací se však také mění povaha moderních měst - vznikají přistěhovalecké čtvrti, ve kterých se starousedlíci nemusí domluvit oficiálním státním jazykem, vznikají nekontrolovaně rostoucí slumy, ale také multikulturnímu soužití nakloněné instituce a veřejné prostory. Migrace je jednou z určujících charakteristik globálního města (Sassen 2001).

Současná nenásilná migrace je často odchodem za modernějšími podmínkami života. Smutnou stránkou věci zůstává, že moderní ideál plné zaměstnanosti domácnosti a perspektivy sociálního vzestupu potomků s pomocí moderních statusových prostředků a vlastní píle se $\mathrm{v}$ současné době zdá být iluzí, kterou ne všichni zájemci mohou trvale naplnit (Keller 2000). Migrace tak z jiné strany znovu otevírá diskusi o sociální nerovnosti a spravedlnosti. Migrující jako by svým pohybem za hranice státu pozbýval/a loajality vnějšího okolí, stává se cizincem existujícím mimo parametry předpokládaných normálních životních podmínek. Michel Maffesoli vnímá zkušenost nejistoty, neustálé změny a existence světa bez pevného středu jako symptom transformace modernity. Nebo: „Jak už se to v lidských dějinách čas od času stává, epocha stabilních struktur či institucí skončila. Modernita a její koreláty byly postaveny právě na nich: na individuu, identitě, národu, státu“ (Maffesoli 2002: 185). Stěhování tedy nakonec nemusí znamenat fyzické přemístění, spíše dnes odkazuje na zvláštní stav mysli a společenské organizace, nejisté, neustále se měnící a relativistické. Viděno z tohoto úhlu, přesunout se pryč nutně naznamená odchod plánovat a záměrně zamýšlet životní změnu. Můžeme se tak zamýšlet nad tím, zda interpretace pohybu migrujících, této statistické menšiny obyvatel planety, nepoukazuje na krizi legitimity geopolitické organizace prostoru 20. století. Jak píše Karen Kaplan (2000: 7): „Pro spoustu z nás možnost zůstat doma v konvenčním smyslu slova neexistuje - myslím tím, že svět se změnil do takové míry, že tyto domácí, národní, respektive vyznačené prostory již neexistuji..“

\section{Závěr}

Bez struktury národních států by neexistovala moderní migrace tak, jak ji chápou popisné vědy, ale ani kriticko-analytické př́stupy. Diskuse nad migračními událostmi se v západní Evropě a Severní Americe v posledních padesáti letech neoddělitelně prolnula s diskusemi o rekonstrukci povahy národních států, ale také o povaze moderních sociálních nerovností. Podíváme-li se na statistiky migrace OSN, vidíme, že za migranta je zde považován člověk pobývající mimo stát, v němž se narodil. Vynořují se ale pojmy, které naznačují, že migrující není tak snadné označit a spočítat. Na jedné straně jsou zde ilegální přistěhovalci, jejichž př́tomnost v imigrantských státech je evidentní, jejichž existence je však postupy konvenční statistiky nezachytitelná. Vnitřní vysídlenci zase s migranty sdílejí osud sociální vykořeněnosti a životní diskontinuity, ale nacházejí se uvnitř státu, kde se narodili. V neposlední řadě dnes existují rodiny a komunity lidí, kteři žijí v transnacionálním sociálním prostoru, který díky rozvoji komunikačních technologií a relativně nízkým nákladům na cestování zpochybňuje dříve neoddělitelný vztah komunity a fyzického prostoru a mění tím vnímání obojího. Úmluva OSN o právním postavení uprchlíků z roku 1951 neseznala od roku 1967 závažnější 
reformulace a termín „falešný uprchlík“ připomíná, že tento legislativní rámec, který vytyčil ostrou hranici mezi dobrovolně a vynuceně migrujícími, nepostihuje změny ve způsobech migrování, které pozorujeme v posledních desetiletích.

V dnešní době již není možné ve výzkumu moderní migrace ignorovat různé existující sociálně-vědné výkladové rámce. Otázkou zůstává možnost jejich skutečného prolnutí v interdisciplinárním výzkumu. Můžeme to vidět právě na statistickém př́istupu k migraci. Navzdory vědomí omezené výpovědní hodnoty těchto ,tvrdých“ dat s nimi bývá zacházeno jako s objektivní reprezentací sociální reality, jen s úvodním upozorněním na jejich omezenou výpovědní kapacitu. Spíše než k velké syntéze všeho vědění o migraci směřují sociální vědy k citlivější kontextualizaci interpretačního rámce, který ten který výzkum používá, stejně jako k co nejpřesnějšímu vymezení oblasti zkoumání. Na druhé straně s rostoucí relevancí mobility je ovšem také možné, že po zohlednění aspektů socio-ekonomické nerovnosti, etnických identit a genderu se v budoucnu dočkáme také zařazení způsobu existence v prostoru s ohledem na mobilitu mezi základní analytické kategorie.

\section{Literatura}

Anderson, B. 1991. Imagined Communities, Reflections on the Origin and Spread of Nationalism. London: Verso.

Bammer, A. (ed.) 1994. Displacements. Cultural Identities in Question. Bloomington: Indiana University Press.

Barša, P.; Baršová, A. 2005. Přistěhovalectví a liberální stát. Imigrační a integrační politiky v USA, západní Evropě a Česku. Brno: Masarykova univerzita v Brně - Mezinárodní politologický ústav.

Bhugra, D. 2004. „Migration and Mental Health.“ Acta Psychiatr Scandinavica 109: 243-258.

Böhning, W. R. 1984. Studies in International Labour Migration. London: Macmillan.

Brettell, B. C. 2003. Anthropology and Migration. Walnut Creek: Altamira Press.

Brettell, C. B.; Hollifield, J. F. (eds.) 2000. Migration Theory. Talking Across Disciplines. New York: Routledge.

Castels, S.; Miller, M. J. 1998. The Age of Migration. International Population Movements in the Modern World. Houndmills: Macmillan Press Ltd., 2. vydání.

Demuth, A. 2000. „Some Conceptual Thoughts on Migration Research.“ In B. Agozino (ed.) Theoretical and Methodological Issues in Migration Research. Aldershot: Ashgate.

Drbohlav, D. 2003. Mezinárodní migrace obyvatelstva - pohyb i pobyt (Alenky v kraji divui). Přednáška zorganizovaná Multikulturním centrem Praha a katedrou pedagogiky FF UK.

Dummett, M. 2001. On Immigration and Refugees. London: Routledge.

Faist, T. 1997. ,The Crucial Meso-Level.“ In T. Hammar, G. Brochmann, T. Faist (eds.) International Migration, Immobility and Development: Multidisciplinary Perspectives. New York: Berg Publishers.

Giddens, A. 1976. New Rules of Sociological Method: a Positive Critique of Interpretative Sociologies. Cambridge: Polity Press.

Grygar, J.; Čaněk, M. ; Černík, J. 2006. Vliv kvalifikace na uplatnění a mobilitu na českém trhu práce u migrantio ze třetích zemí. Praha: Multikulturní centrum. Srpen 2006.

Hobsbawm, E. 2000. Národy a nacionalismus od roku 1780. Brno: CDK. 
IDMC. 2006. Internal Displacement. Global Overview of Trends and Developments in 2005. Internal Displacement Monitoring Centre. March 2006.

Kaplan, C. 2000. Questions of Travel. Postmodern Discourses of Displacement. Durham: Duke University Press.

Keller, J. 2000. Vzestup a pád střednich vrstev. Praha: SLON.

Kuhn, T. S. 1997. Struktura vědeckých revolucí. Praha: OIKOYMENH.

Lee, E. S. 1966. „A Theory of Migration.“ Demography, 3 (1): 47-57.

Maffesoli, M. 2002. O nomádství. Iniciační toulky. Praha: Prostor.

Martin, P.; Windgren, J. 2002. „International Migration: Facing the Challenge.“ Population Bulletin, 57 (1).

Massey, D. S. a kol. 1993. „Theories of International Migration: a Review and Appraisal.“ Population and Development Review, 19 (3) September 1993.

Massey, D. S.; Goldring, L.; Durand, J. 1994. „Continuities in Transnational Migration: an Analysis of Nineteen Mexican Communities.“ American Journal of Sociology, 99 (5).

Mateos, R. N. 2000. „Notes on a Southern European Model: Immigration, the Welfare State and the Family.“ In: B. Agozino Theoretical and Methodological Issues in Migration Research. Aldershot: Ashgate.

Mc Hugh, K. E.; Hogan, T. D.; Happel, S. K. 1995. „Multiple Residence and Cyclical Migration: a Life Course Perspective." Professional Geographer, 47 (3).

Morawska, E. 2003. „Disciplinary Agendas and Analytic Strategies of Research on Immigrant Transnationalism: Challenges of Inter-disciplinary Knowledge.“ International Migration Review 37 (3) (Fall 2003).

Orellana, F. M.; Thorne, B.; Chee, A.; Lam, E. S. Wan. 2001. „Transnational Childhoods: The Participation of Children in Process of Family Migration." Social Problems 48 (4): 572-591.

Portes, A. 1997. „Immigration Theory for a New Century: Some Problems and Opportunities.“ Intenational Migration Review, 31: 893-922.

Rabušic, L.; Burjanek, A. 2002. Imigrační politika jako prvek řě̌ení české demografické situace? Brno: Výzkumný ústav práce a sociálních věcí Praha; Výzkumné centrum Brno.

Ravenstein, E. G. 1898. „The Laws of Migration.“ Journal of the Royal Statistical Society: 241-301. Sassen, S. 2001. The Global City. New York: Princeton University Press.

Vertovec, S. 2004. Trends and Impacts of Migrant Transnationalism. Working Paper No. 3. Oxford: Centre on Migration, Policy and Society, University of Oxford.

\section{Dokumenty}

Český statistický úřad. 2005. Cizinci podle kategorií pobytu a státního občanství - 25 nejčetnějších státních občanství - k 31. 12. 2005. [Cit. 29. 9. 2006] Dostupný z: <http: //www.czso.cz/ciz/cizinci.nsf/i/datove_udaje_pocet_cizincu_v_cr>

OSN. Department of Economic and Social Affairs, Population Division. 2006. International Migration 2006. United Nations Publication Sales No. E.06.XIII.6.

Protokol ze dne 29. ledna 1967 vztahující se k poskytování azylu osobám, které jsou v nebezpečí pronásledování.

Směrnice Rady 2004/83/ES ze dne 29. dubna 2004 o minimálních normách, které musí splňovat státní příslušníci třetích zemí nebo osoby bez státní př́slušnosti, aby mohli žádat 
o postavení uprchlíka nebo osoby, která z jiných důvodů potřebuje mezinárodní ochranu, a o obsahu poskytované ochrany.

Úmluva OSN o právním postavení uprchlíků ze dne 28. července 1951.

Výzkum 2004. Výzkum v rámci projektu MlaDěRo projekt č. 15 ,Migrace marginalizovaných rodin jako jejich životní strategie“, Mgr. Kateřina Janků, PhDr. Csaba Szaló, Ph.D., FSS MU Brno. Výzkum k disertační práci „Migrace jako životní strategie marginalizovaných rodin.“ Nepublikované poznámky z návštěv v rodinách a rozhovorů s imigranty a jejich príbuznými.

Výzkum 2006. Výzkum k projektu „Vliv kvalifikace na uplatnění a mobilitu na českém trhu práce u imigrantů ze třetích zemí.“ Mgr. Kateřina Janků. Nepublikované nestrukturované hloubkové rozhovory s imigranty. Výzkum v rámci projektu Technologického parku, o.p.s. ,Trh práce a cizinci financovaného EU a státním rozpočtem ČR“ (Phare 2003 RLZ - Opatření 1.1 Posílení aktivní politiky zaměstnanosti).

\section{Autorka}

Kateřina Janků působí na Katedře sociální geografie a regionálního rozvoje Přírodovědecké fakulty Ostravské univerzity v Ostravě. Je spolupracovnicí Multikulturního centra Praha a členkou redakční rady portálu www.migraceonline.cz. Zabývá se etnografickým výzkumem migrace, na Katedře sociologie FSS MU píše disertační práci o slovensko-českých romských rodinách, které mají zkušenost s migrací na západ po roce 1993. Kontakt: katerina.janku@osu.cz 